\title{
Biology Learning Resource Design Based on Guided Inquiry
}

\author{
Yolanda Rezki Amallia ${ }^{1 *}$, Linda Advinda ${ }^{1}$
}

\author{
${ }^{1}$ Biology Department, Math and Natural Science Faculty, Universitas Negeri Padang, Padang, Indonesia \\ *Corresponding author. Email:yoandarezkiamallia@gmail.com
}

\begin{abstract}
Learning is interaction process between student with teacher and learning resources in a learning environment. So, the important factor to push a student to get a success in learning process is learning resources. One example of a printed learning resources that can be used in the learning process is a module. Purpose of this research are to result valid and practice learning module based on guided inquiry for Senior High School. This research used Plomp Models: preliminary research, development or prototyping phase, and assessment phase. Subject for this research is 35 students from Senior High School 7 Padang. This research used primary data that was collect directly from validation and practicality questionnaires. The result shows that learning module have $87,38 \%$ in validity and $88,11 \%$ in practicality by students and $88,57 \%$ in practicality by teacher. It can conclude that learning module based on guided inquiry have valid and practice to use in biology learning.
\end{abstract}

Keywords: Biology Learning Resource, Guided Inquiry, Learning Module.

\section{INTRODUCTION}

Education is an effort to prepare students through the activities of guidance, teaching, and training for their role in the future. This concept is appropriate with the Law on National Education System No. 20 of 2003, which states that education is a conscious and planned effort to create an atmosphere of learning and learning process so that students actively develop their potential to have spiritual strength, self-control, personality, intelligence, noble character, and the skills needed by themselves, society, nation and state.

The government has made efforts to improve the quality of education in Indonesia, one of which is by applying the 2013 Curriculum as a complement to the Education Level Unit Curriculum (KTSP) for all levels of education in Indonesia. Permendikbud No. 69 of 2013 states that the aim of the 2013 curriculum is to prepare Indonesian people to have the ability to live as individuals and citizens who are faithful, productive, creative, innovative, and effective and able to contribute to the life of society, nation and state [13]. The 2013 curriculum adheres to the basic view that knowledge cannot be transferred from teacher to student. Students are subjects who have the ability to actively search, process, construct, and use knowledge. For this reason, learning must be related to the opportunities given to students to construct knowledge in their cognitive processes
Biology as a science is basically in the form of concepts, facts, principles, theories and procedures that must be understood by students through active involvement in the learning process. The knowledge and skills acquired by students are not the result of remembering a set of facts, but the results from discovering themselves [32]. Like the opinion expressed by Lufri, the characteristics of biology students are children who in the learning process enjoy interacting with the universe, especially living things and their environment [17]. Science has a strategic function because it can be used to develop the potential and abilities of students in both aspects of knowledge, skills and attitudes [20]. Anderson \&Krathwol stated that learning outcomes include three domains, namely cognitive, psychomotor, and affective [4]. However, in reality at this time activities in schools tend to be carried out learning activities that are centered on the teacher (teacher centered), so that more students accept what is given by the teacher without trying to be actively involved in it so as not to hone the skills and attitudes of students. Mulyasa said that it was a hereditary condition where the teacher dominated learning activities through lecture activities [19].

The science process of students can be built by providing learning experiences with guided inquiry learning models. The inquiry learning model is one of the recommended learning models in the 2013 curriculum [14]. The use of inquiry approaches can make students actively involved in the classroom [11]. Lederman et al. stated that the best students learn science through inquiry-oriented teaching 
[15]. The inquiry process during learning has a constructive impact which provides many opportunities to improve the effectiveness of teaching and learning [38]. Based on the results of conducted interviews on three biology teachers at three schools in Padang City, said that; (1) the teacher has made teaching subjects that are adapted to the demands of the curriculum but those are just in certain chapters, the rest of it using textbooks from publishers; (2) on the used textbook, there are subjects those are not accordance with the demands of basic competencies; (3) on the used textbook, there are misconceptions, for example protist that is similar to the plant and animal; (4) the used teaching subject in books by students are not systematic or overlapping; (5) the used teaching subject contains inquiry phases but implicit and incomplete; (6) students have difficulty to understand Animalia subject, especially Invertebrate because the animals are less familiar, the scope is too broad and students have low interest for reading.

The results of questionnaire analysis by 92 respondents at 3 schools in the Padang city can be concluded that; (1) not all students have their own textbooks, some of them only depend on books that are loaned from schools; (2) according to students, difficult subject is archaebacteria and eubacteria, plantae and animalia. There are $67.39 \%$ of students had difficulty with archaebacteria and eubacteria, $60.87 \%$ in plantae subject and $58.69 \%$ in animalia subject; (3) the difficulty to understand biological subject is caused by several things such as: subject is abstract and cannot be directly observed, many terms are confusing, the language at the book is difficult to understand, and too much subject.

One effort to improve the quality of education at school is using quality learning resources. The learning module is one of the learning resources that allows students to learn independently. This can help students to understand a lot of subjects with or without teacher guidance. The module is one of the teaching subjects that is in accordance with the characteristics of the 2013 curriculum, such as learning process ideally can involve students actively and not only emphasize the cognitive aspects but also psychomotor and attitude aspects [22]. Learning by using module is useful for the following: (1) increasing effectiveness; (2) determine and establish more suitable study time by the students' needs and development learning; (3) find out achievement of student competencies in stages through set out criteria in the module; (4) find out the weaknesses or competencies that have not been achieved by students based on the set out criteria in the module [8].

Some research results show that the use of modules in the learning process can improve learning outcomes [2], [10], [34], [23]. Taneja describes the module as a work unit that allows students to learn independently and as a learning method based on the concept of the formation of skills and knowledge [39]. Loughran and Berry said that lecturing is not a teaching process and listening is not a learning process, but rather a process of absorbing concepts and expressing these concepts through independent learning [16]. Based on the problems that have been revealed, a learning design has been carried out in the form of an inquiry-based learning module for Plantae and Animalia subjects for high school students at grade $\mathrm{X}$.

\section{METHODS}

This type of research was aPlomp model development research which consisted of preliminary research phase, development or prototyping phase (development or prototyping phase), and assessment phase (assessment phase) [27]. This researchwas aimed atproducing products in the form of an inquiry-based learning module for Plantae and Animalia subjects. This research was conducted at the Faculty of Mathematics and Natural Sciences (FMIPA) of Universitas negeri Padang (UNP) and SMAN 7 Padang in 2018/2019Academic Year. The data in this research were obtained from the validity and practicality test questionnaire. These data were included in the primary data, i.e. the data obtained directly from research subjects. The instruments used included: 1) selfevaluation sheets, 2) validation questionnaires, 3) one to one evaluation questionnaires, 4) small group evaluation questionnaires, and 5) practicality questionnaires.

\subsection{Preliminary Research Phase}

The preliminary research phase aims to find out the basic problems in learning biology in schools. Activities at this phasewere in the form of observation, analytical gathering and defining the problems that occured in the learning process. This phase began with an analysis of problems and needs in learning, curriculum, students, and teaching subjects used in schools.

\subsection{Development or Prototyping Phase}

This phase started after the preliminary research phase was completed. This phase consisted of microscopes that helped in developing and improving products. This phaseconsisted of several stages of making a prototype as follows.

\subsubsection{Development of Prototype I}

The results of the prototype design in the initial stages are called prototype I. The initial design is done by researchers based on the results of preliminary research that has been done.

\subsubsection{Development of Prototype II}

Prototype II was the development phase by conducting a self-evaluation using a checklist. Self-evaluation (selfevaluation) was revising the modules that have been designed. The evaluation method itself carried out was 
aimed at examining the errors that exist in the module, so it obtained relevant product criteria based on science and consistent with expected.

\subsubsection{Development Prototype III}

Prototype II was then consulted with experts (expert review) and one to one evaluation. Consultation with experts (expert review) was carried out based on expert judgment (validator) from the didactic, construct, and technical aspects. This evaluation was carried out using an expert validation sheet. The data validitywas obtained by analyzing the validation questionnaire that has been filled out by the validator. The analysis was carried out with the following steps.

1) Give a score of answers to each indicator with criteria based on scale 1-4.

2) All items given a score were then tabulated and the percentage was searched using the following formula.

$$
\text { Validity }=\frac{\text { itemscoreobtained }}{\max \text { imumscore }} \times 100 \%
$$

Table 1.The Module Validity Criteria

\begin{tabular}{|l|l|}
\hline Validity $(\%)$ & Category \\
\hline $81-100$ & Very Valid \\
\hline $61-80$ & Valid \\
\hline $41-60$ & Adequate Valid \\
\hline $21-40$ & Less Valid \\
\hline $0-20$ & Invalid \\
\hline
\end{tabular}

Modified from Riduwan (2009) [31]

At the same time one to one evaluations were carried out on three class $\mathrm{X}$ students using interview guide sheets. The results of the revised Prototype II are called Prototype III.

\subsubsection{Development Prototype IV}

Prototype III was evaluated through small group evaluation. At this phase an evaluation of six high school students at grade $\mathrm{X}$ was low, medium, high ability levels; each consisting of two members. This formative evaluation used a student practice questionnaire sheet. The results of the revised Prototype III were called Prototype IV.

\subsection{The Assesment Phase}

Field tests or large group trials (field tests) were carried out to see the practicality of the modules that have been designed. Practicality is the level of practicality of the module when it is used in the learning process. The research data obtained were analyzed by qualitative and quantitative analysis. Data for the initial investigation, design and construction stages were analyzed qualitatively and presented in descriptive form. The practicality data of the use of the learning module is analyzed by percentage $(\%)$, using the following formula.

$$
\text { Practicality }=\frac{\text { I tems coreobtained }}{\text { Maximumscore }} \times 100 \%
$$

After the percentage was obtained, grouping was done according to the following criteria.

Table 2.The Module Practicality Criteria

\begin{tabular}{|l|l|}
\hline Validity (\%) & Category \\
\hline $81-100$ & Very Practical \\
\hline $61-80$ & Practical \\
\hline $41-60$ & Adequate Practical \\
\hline $21-40$ & Less Practical \\
\hline $0-20$ & Unpractical \\
\hline
\end{tabular}

Modified from Riduwan (2009) [31]

\section{RESULT AND DISCUSSION}

\subsection{Result}

\subsubsection{Preliminary Research Phase Result}

The preliminary research phase aims to find out the basic problems in learning biology in schools. Activities at this phasewere in the form of observation, analytical gathering and defining the problems that occured in the learning process. The results of research conducted by Amallia and Advinda revealed that first, teaching subjects used by students focused on science as a product, not as a process. Second, the presentation of subject on teaching subjects for students has not been based on one of the learning models recommended in the 2013 curriculum. Third, the existing learning resources have not been able to motivate students to learn. The learning resources used were not colored, the supporting images of the subject seemed unclear and the examples presented were less familiar. Fourth, the presentation of subject about the teaching subjects of students was not systematic and not appropriate with the demands of basic competencies in the 2013 curriculum [3].

\subsubsection{Development or Prototyping Phase Result}

This research started from the design and manufacture of guided inquiry-based learning module products. The guided inquiry steps contained in the developed module were aimed at enabling students to develop scientific attitudes during learning. According to Pedaste, et al., modulesare designed in the order of steps of the inquiry model: orientation conceptualization, investigation, conclusion, and discussion [26]. Learning by using guided inquirybased modules was aimed atproviding a way for students to build thinking skills. Watcharee et al said that inquiry presents case-based case studies so as to enable students to build their own conceptual understanding [40]. Inquiry learning is learning that maximally involves all abilities including knowledge, attitudes and skills of students to look for and investigate something (objects, people or events), systematically, critically, logically, and analytically [14]. 
Anderson believes that inquiry is the essence of learning [4].

Modules were created by using the 2007 Microsoft Office Publisher application. The components in this guided inquiry-based module were the module cover, preface, table of contents, list of images, instructions for using the book, module profiles, competency review, concept maps, cover topics, inquiry steps, the science info column, the discussion column, the independent task column, the motivation column, summary, understanding check, evaluation, glossary, answer key, bibliography, and author biography. The design results at this phase were called prototype I.

The resulting prototype I was followed by a self-evaluation. In this activity a review of the important components in the learning module that has been developed used a checklist. At this phase a revision of some writing errors was made and the addition of the word "see picture" to clarify the image referred to in the description of the subject. The results of the revised prototype I were called prototype II.

Prototype II was then subjected to expert review and one to one evaluation. The expert evaluation activity was carried out by looking at the validity of the learning module based on the validator's assessment which included three aspects: didactic, construct and technical. Based on the assessment given by the validator, it can be seen that the validity of the learning modules for each aspect is in the very valid category. The module validity results can be seen in Table 3 .

Table 3. The results of the module validity questionnaire analysis

\begin{tabular}{|l|l|l|}
\hline $\begin{array}{l}\text { Assessment } \\
\text { Aspects }\end{array}$ & Persentage(\%) & Category \\
\hline Didactic & 90,62 & Very valid \\
\hline Construct & 87,50 & Very valid \\
\hline Technical & 84,03 & Very valid \\
\hline Mean of Validity & 87,38 & Very valid \\
\hline
\end{tabular}

In addition to providing validator ratings, it also provided suggestions for improvements to the modules developed. The suggestions given by the validator can be seen in Table 4. Then, the module was revised according to the suggestions of each validator.

Table 4. Suggestions and follow-up from the validator to the module

\begin{tabular}{|l|l|}
\hline Suggestions & Follow-up \\
\hline $\begin{array}{l}\text { Improve the use of words } \\
\text { and capital letters. }\end{array}$ & $\begin{array}{l}\text { The use of words and capital } \\
\text { letters has been improved. }\end{array}$ \\
\hline $\begin{array}{l}\text { Numbering description is } \\
\text { missing. }\end{array}$ & $\begin{array}{l}\text { Numbering description in } \\
\text { the picture has been added. }\end{array}$ \\
\hline
\end{tabular}

\begin{tabular}{|l|l|}
\hline Suggestions & Follow-up \\
\hline $\begin{array}{l}\text { Captions still exist in } \\
\text { English. }\end{array}$ & $\begin{array}{l}\text { The caption of picture has } \\
\text { been translated into } \\
\text { Indonesian. }\end{array}$ \\
\hline $\begin{array}{l}\text { The use of scientific names } \\
\text { is not appropriate with the } \\
\text { rules of writing scientific } \\
\text { names. }\end{array}$ & $\begin{array}{l}\text { Writing a scientific name is } \\
\text { appropriatewith the rules of } \\
\text { writing a scientific name. }\end{array}$ \\
\hline $\begin{array}{l}\text { The writing is too long, } \\
\text { correct the margins. }\end{array}$ & Margin has been fixed. \\
\hline $\begin{array}{l}\text { Rearrange the layout on the } \\
\text { pageAnnelida structure and } \\
\text { function. }\end{array}$ & $\begin{array}{l}\text { Layout on the page Anelida } \\
\text { structure and function has } \\
\text { been improved. }\end{array}$ \\
\hline $\begin{array}{l}\text { Add an exclamation point } \\
\text { (!) each command } \\
\text { sentence. }\end{array}$ & $\begin{array}{l}\text { An exclamation mark (!) has } \\
\text { been added to each } \\
\text { command sentence. }\end{array}$ \\
\hline $\begin{array}{l}\text { Improve writing the word } \\
\text { "Do'a". }\end{array}$ & $\begin{array}{l}\text { Writing the word "Do'a"has } \\
\text { been improved to "Doa". }\end{array}$ \\
\hline $\begin{array}{l}\text { Writing the information } \\
\text { "Glass A and B" } \\
\text { repeatedly. }\end{array}$ & $\begin{array}{l}\text { Writing information about } \\
\text { Glass A and B has been } \\
\text { replaced. }\end{array}$ \\
\hline $\begin{array}{l}\text { Fix writing the word } \\
\text { "regeration". }\end{array}$ & $\begin{array}{l}\text { The word regeration has } \\
\text { been corrected } \\
\text { "regeneration". }\end{array}$ \\
\hline
\end{tabular}

Furthermore, one to one evaluations were conducted to obtain responses and input from the students' perspective of the modules developed. One to one evaluation was conducted on 3 students with high, medium and low level academic abilities. The revised results of prototype II were called prototype III.

Prototype III then was evaluated by a small group to get improvement and affirmation from the previous evaluation of the practicality of the module. The number of students in the small group test conducted was six people with varied academic abilities from the population (high, medium, and low). Thevaried abilities of students were intended so that the responses and suggestions given by students represented class population. The results of the small group evaluation provided information that the modules produced were already in the practical category to be used with a percentage of $88.04 \%$. The results of the revised prototype III were called prototype IV.

\subsubsection{Assesment Phase Result}

Prototype IV was then carried out a field test (field test) of 35 students oat grade $\mathrm{X}$ of SMAN 7 Padang and one biology teacher. The field test was aimedat seeing the practicality of using guided inquiry-based learning modules developed in the learning process. The results of practicality tests by students can be seen in Table 5 and the teacher in table 6. 
Table 5.The Practicality Test Results for Guided InquiryBased Learning Modules by Students

\begin{tabular}{|l|l|l|}
\hline Aspects & $\begin{array}{l}\text { Percentage } \\
(\%)\end{array}$ & Category \\
\hline Ease of Use & 88.77 & Very practical \\
\hline Time required & 80.00 & Practical \\
\hline Attractiveness & 92.86 & Very practical \\
\hline Ease of interpretation & 87.50 & Very practical \\
\hline Has Equivalence & 91.43 & Very practical \\
\hline Mean of Practicality & 88.11 & Very practical \\
\hline
\end{tabular}

Based on Table 5 it is known that the average practicality assessment given by $\mathrm{X}$ class students is $88.11 \%$ with very practical criteria. This shows that guided inquiry-based modules are practically used by students in the biology learning process.

Table 6.The Results of Practicality Tests for Guided Inquiry-Based Learning Modules by Teachers

\begin{tabular}{|l|l|l|}
\hline Aspects & $\begin{array}{l}\text { Percentage } \\
(\%)\end{array}$ & Category \\
\hline Ease of Use & 92.86 & Very practical \\
\hline Time required & 75.00 & Practical \\
\hline Attractiveness & 87.50 & Very practical \\
\hline Ease of interpretation & 87.50 & Very practical \\
\hline Has Equivalence & 100.00 & Very practical \\
\hline Mean of Practicality & 88.57 & Very practical \\
\hline
\end{tabular}

Based on Table 6 it is known that the mean of practicality assessment given by biology subject teachers was $88.57 \%$ with very practical criteria. This shows that guided inquirybased modules are practically used by teachers in the biology learning process.

\subsection{Discussion}

This research resulted in a product in the form of a guided inquiry-based learning module. This module was developed using various letters such as the letters Maiandra GD, Roman Times News, and ITC Christians. This was appropriate with the questionnaire needs of students who wanted teaching subjects by using letters that vary. The teaching subject template used was dominated by green and white. The green color was chosen because the topic of discussion was related to nature, especially Plantae and Animalia. According to Rider and Monica and Laura the green color gives a happy impression. This is mainly related to nature, trees, and plants, which often provide a calming quality [30], [18]. The same thing is said by
Wiseman that green is associated with positive things such as calmness. Meanwhile, white color is associated with light, purity and simplicity [41]. A white product is a very good and effective balancing color in treating headaches [14].

The validation of the guided inquiry-based learning module was carried out by 4 validators. The data analysis from the validity assessment sheet of this module was reviewed from the aspects of didactics, constructs, and techniques. Sugiyono [13] stated that validity is the degree of accuracy between the data that occurs in the research object with the actual data. The results of the module validation data analysis showed that the guided inquiry-based learning module had a validity value of 87.38 with very valid criteria.

The didactic aspects of guided inquiry-based modules were declared valid by a validator with a value of 90.62 with very valid criteria. From these criteria it can be seen that the modules developed are appropriate with the 2013 Curriculum related to Core Competencies (KI) and Basic Competencies (KD). This was appropriate with the Ministry of National Education which stated that the preparation of subject in student books was very dependent on the KD to be achieved [9]. In this module, KI developed were $\mathrm{KI} 3$ and 4, and specifically in $\mathrm{KD} 3.8,3.9,4.8$ and 4.9 regarding Plantae and Animalia subjects. The elaboration of the subject presented has supported the achievement of competency achievement indicators, supported students' understanding of the concept, and integrated the steps of guided inquiry, and supported students in scientific work and independent learning.

The construct aspect was declared valid with a value of 87.50 with very valid criteria. Based on this it can be concluded that the guided inquiry-based module has been equipped with a clear identity, a systematic arrangement, using language that is in accordance with good and correct Indonesian language rules, communicative and the use of appropriate terms. The language aspect is one aspect that needs to be considered in the preparation of teaching subjects, the language used should be a language that is simple and easy to understand [12].

The technical aspects were declared valid by the validator with a validity value of 84.03 with very valid criteria. Based on this it is concluded that the guided inquiry-based module uses readable typeface, suitable font size and proper use of punctuation. The pictures used as attractive supporters, according to the concept and accompanied by information that was easy to be understoond. This is also supported by Sudjana's opinion that picture illustrations help students in understanding and remembering the accompanying subject [35]. In addition, the guided inquirybased module has also been compiled with an attractive display and color combination. The colors used in making media are colors that give a harmonious impression so that students can focus on their observations and can take important messages from the media [35]. The color of the module is dominated by white and green, where green gives the natural impression of the module appropriates with the subject. 
The three aspects of evaluating the learning module validation above were a unified whole and mutually supporting to develop a good learning module according to the rules. The validation of the learning modules carried out was very important. Arikunto stated that if a data generated from a product is valid, it can be said that the product developed has provided a description of the development goals correctly and in accordance with the actual situation [6]. A very valid assessment of the guided inquiry-based learning module developed can already be used as a guide in learning.

One to one evaluation that has been valid according to experts was carried out. Based on this one to one evaluation, information was obtained that the development of guided inquiry-based learning modules was welcomed by students. This is because the developed learning module has a good display, writing, drawing, and grammar as well as the guided inquiry steps in the learning module that are easy to understand and help students in carrying out learning activities.

Furthermore, a small group evaluation (Small Group Evaluation) was carried out through a practicality questionnaire given to 6 students whose aim is to see the practicality of the guided inquiry-based module before conducting the field test. The results of the practicality of the small group received a very practical category with a value of 88.04 with a very practical category. This was because the students feel the module was easy to use, interesting, and helps the students in the learning process at school and was equivalent to teaching subjects commonly used at school. In line with Prastowo's opinion, the selection criteria for teaching subjects are practical and simple. However, the practicality of small groups for time usage indicators is classified as practical because students are not accustomed to using this module in the learning process [28].

Large group practicality tests (field tests) were conducted by students and teachers with a mean practicality s of 88.11 by students and 88.57 by teachers in very practical categories. Based on the results of field tests and assessments by the teacher the inquiry-based learning module developed provided convenience in terms of its use. This was because the guided inquiry-based learning module developedin writing was easy to read, had a module profile, the language used was easy to understand, a complete description of the subject and helped understanding concepts, equipped with clear images, and helped thethe students to learn independently. In addition,

\section{CONCLUSION}

Based on the research that has been done, it can be concluded that a learning design has been produced in the form of guided inquiry-based biology learning modules on Plantae and Animalia subjectsin valid and practical criteria for high school students at grade X. the module has the same size as teaching subjects commonly used by students.

Judging from the aspects of time required in implementation, the guided inquiry-based learning module was quite practical. This shows the use of this module appropriate with the available time, which does not involve a long time and does not interfere with other learning time so that it can be said this guide is efficient to use. According to Sukardi, practicality can be seen from the implementation time which should be short, fast, and precise [37]. In order to use time more efficiently, the frequency of use of modules in learning should be increased so that students are able to allocate learning time using modules properly.

In terms of the attractiveness of the guided inquiry-based learning module developed, this module had a very practical category. From the criteria obtained in this aspect, it is known that the module can help teachers increase the interest and motivation of students in carrying out learning activities. That was because the display of guided inquirybased learning modules had interesting and varied colors and images. Barnes et al suggested that learning using modules can motivate students [7].

In terms of ease of interpretation, guided inquiry-based learning modules had very practical criteria. This was because the inquiry step in the module was easily understood by teachers and students. The guided inquirybased learning module developed was also able to make the students more active in conducting scientific activities.

In terms of equivalence, the guided inquiry-based learning module had very practical criteria. This shows that the guided inquiry-based module has equality of subject with commonly used teaching subjects, so that it can be an alternative teaching subject in the learning process. Similarly,Sukardi stated that learning media is said to be equivalent if it can be used as a substitute or variation in learning in accordance with the curriculum used [37]. Research conducted by Puti and Setiawati revealed that guided inquiry-based modules can improve students' scientific process skills and attitudes [29], [33]. This was also proven by Novana that the use of guided inquiry modules could improve the student achievement, attitudes, and skills in learning [21]. Ozdilek stated that guided inquiry teaching methods based on qualitative and quantitative findings indicate the level of success and effectiveness of students [25].

\section{REFERENCES}

1. Alberida, H., Arsih, F., Helendra, H., \& Fadilah, M. 2017. "Rancangan Pembelajaran Gerak Makhluk Hidup Melalui Model Pembelajaran Inkuiri Dan Literasi Sains". Jurnal Eksakta Pendidikan (JEP), 1(1), 24-32.

2. Ali, R., Ghazi, S.R., Khan, M.S., Hussain, S., Faitma, Z.T. 2010. "Effectiveness of Modular 
Teaching in Biology at Secondary Level". Asian Social Science. Vol. 6, No. 9 ISSN 1911-2017.

3. Amallia, Y., and Advinda L. 2019. "Need Analysis Development of Guided Inquiry Based Learning Module in Plantae and Animalia Learning Subjects for Student of Senior High School Grade X". International Journal of Progressive Sciences and Technologies (IJPSAT). Vol. 16 No. 1 August 2019, pp. 85-90.

4. Anderson, R. D. 2002. Reforming science teaching: What Research Says About Inquiry. Journal of Science Teacher Education, 13(1), 1-12

5. Anderson, L. W, \& Krathwohl, D. R, et al. 2010. Pembelajaran, Pengajaran dan Asesmen. Yogyakarta: Pustaka Belajar.

6. Arikunto, S. 2012. Dasar-dasar Evaluasi Pendidikan, Edisi 2. Jakarta: Bumi Aksara.

7. Barnes, J., P. Mayer, R. Alfred and Hayman. 2000. Modularization of Curriculum at Secondary Level. Kogan Page, London, UK. pp. 67-98.

8. Depdiknas. 2008. Penulisan Modul. Jakarta: Direktorat Tenaga Kerja Kependidikan Direktorat Jendral Peningkatan Mutu Pendidik dan Tenaga Kependidikan Departemen Pendidikan Nasional.

9. Depdiknas. 2008. Panduan Pengembangan Bahan Ajar. Jakarta: Direktorat Jenderal Manajemen Pendidikan Dasar dan Menengah.

10. Dewi, A. P., Sarwanto., \& Prayitno, B. A. 2014. Pengembangan Modul IpaTerpadu Untuk Smp/Mts Berbasis Eksperimen Pada Tema Fotosintesis Untuk Memberdayakan Keterampilan Proses Sains. Jurnal Inkuiri, Vol 3, No. III, (hal 30-40).

11. Farrell, J. J., Moog, R. S., \& Spencer, J. N. 1999. "A Guided-Inquiry General Chemistry Course". Journal of Chemical Education, 76(4), 570.

12. Hamdani. 2011. Strategi Belajar Mengajar. Bandung: CV Pustaka Setia.

13. Kemendikbud. 2013. Peraturan Menteri Pendidikan Pendidikan dan Kebudayaan Republik Indonesia Nomor 69 Tahun 2013 Tentang Kerangka Dasar dan Struktur Kurikulum Sekolah Menengah Atas /Madrasah Aliyah. Jakarta: Kemendikbud.

14. Kemendikbud. 2016. Modul Pelatihan Kurikulum 2013 Revisi 2016. Jakarta: Kementerian Pendidikan dan Kebudayaan.
15. Lederman, N. G., Lederman, J. S., \& Antink, A. 2013. Nature of Science and Scientific Inquiry as Contexts for The Learning of Science and Achievement of Scientific Literacy. International Journal of Education in Mathematics, Science and Technology, 1(3)

16. Loughran, J. and Amanda, B. 2000. Improving Teacher Education Practice through Self Study. Routledge flamer 28 West 35th Street New York, USA. p. 28.

17. Lufri. 2007. Strategi Pembelajaran Biologi: Teori, Praktik, dan Penelitian. Padang: UNP Press.

18. Monica, dan Laura, C. L. 2011. Efek Warna dalam Dunia Desain dan Periklanan. Humaniora. Vol.2 No.2 Oktober 2011: 1084-1096.

19. Mulyasa. 2013. Pengembangan dan Implementasi Kurikulum 2013. Bandung: PT. Remaja Rosdakarya.

20. Mundilarto. 2005. Pendekatan Kontekstual Dalam Pembelajaran Sains. PPM Terpadu SMPN 2 Mlati. Yogyakarta: 20 Agustus 2005

21. Novana, T. 2014. Pengembangan modul Inkuiri Terbimbing Berbasis Potensi Lokal pada Materi Tumbuhan Lumut (Bryophyta) dan Tumbuhan Paku (Pteridophyta). Jurnal Inkuiri. ISSN: 22527893, Vol 3, No. II, 2014

22. Novitasari, Erma., Mohammad Masykuri., Nonoh Siti Aminah. 2016. Pengembangan Modul Pembelajaran IPA Terpadu Berbasis Inkuiri Terbimbing Tema Matahari Sebagai Sumber Energi Alternatif Di Kelas Vii SMP/MTs. Jurnal Inkuiri. ISSN: 2252-7893, Vol 5, No. 1, 2016 (hal 112-121).

23. Nugroho, Anwari Adi., Singgih Subiyantoro. 2017. Pengembangan Modul Sistematika Tumbuhan Tinggi Berbasis Guided Discovery untuk Mengembangkan Kemampuan Berpikir Kritis Mahasiswa Pendidikan Biologi. BioPedagogi: Jurnal Pembelajaran Biolog.i Volume 6, Nomor 2 Halaman 19-24 P-ISSN: 2252-6897

24. Nurhidayah, Rizki., Dedi Irwandi, Nanda Saridew. 2015. Pengembangan Modul Berbasis Inkuiri Terbimbing Pada Materi Larutan Elektrolit Dan Non-Elektrolit. EDUSAINS. 7 (1), 2015, 36-47

25. Ozdilek, Z. (2009). The Effect of a Guided Inquiry Method on Pre-service Teachers' Science Teaching Self-Efficacy Beliefs. Volume 6, Issue 2. 
26. Pedaste, M., Mäeots, M., Siiman, L. A., De Jong, T., Van Riesen, S. A., Kamp, E. T., \& Tsourlidaki, E. 2015. "Phases of Inquiry-Based Learning: Definitions and The Inquiry Cycle". Educational research review, 14, 47-61.

27. Plomp, Tjeerd., and Nieveen, Nienke. 2013. Educational Design Research: An Introduction. Enschede: SLO. Netherlands Institute for Curriculum Development.

28. Prastowo, A. 2011. Panduan Kreatif Membuat Bahan Ajar Inovatif. Yogyakarta: Diva Press.

29. Puti, S. dan Jumadi. 2015. "Pengembangan Modul IPA SMP Berbasis Guided Inquiry untuk meningkakan keterampilan proses dan sikap ilmiah". Jurnal Pendidikan Matematika dan Sains Tahun III. No 1, Juni 2015.

30. Rider, R. M. 2009. Color Psychology and Graphic Design Applications. Senior Honors Papers, 111.

31. Riduwan. 2009. Belajar Mudah Penelitian untuk Guru-Karyawan dan Peneliti Pemula. Bandung: Alfabeta.

32. Riyanto, Yatim. 2009: Paradigma Baru Pembelajaran. Jakarta: Kencana.

33. Setiawati, R. 2013. Pengembangan Modul Berbasis Inkuiri Terbimbing untuk Mengoptimalkan Sikap Ilmiah Peserta Didik pada Pokok Bahasan Listrik Dinamis di SMA N 8 Purworejo Kelas X Tahun Pelajaran 2012/2013. Radiasi.Vol.3.No.1.

34. Setiyadi, Muhammad Wahyu., Ismail., Hamsu Abdul Gani. 2017. Pengembangan Modul Pembelajaran Biologi Berbasis Pendekatan Saintifik Untuk Meningkatkan Hasil Belajar Siswa. Journal of Educational Science and Technology. Volume 3 Nomor 2 Agustus 2017 Hal. 102- 112 p-ISSN:2460-1497 dan e-ISSN: 2477-3840

35. Sudjana, N dan Rivai, A. 2011. Media Pengajaran. Bandung: Sinar Baru Algensindo.

36. Sugiyono. 2012. Statistika untuk Penilaian. Bandung: Alfabeta.

37. Sukardi. 2008. Evaluasi Pendidikan Prinsip dan Operasionalnya. Yogyakarta: Bumi Aksara.

38. Suprihatiningrum, J. 2016. Strategi Pembelajaran: Teori \& Aplikasi. Yogyakarta: Ar-Ruzz Media.
39. Taneja, R. 1989. Dictionary of Education. Anmol Publication Murare New Dehli, India. p. 155.

40. Watcharee. et al. 2010. Enhanced learning of biotechnology students by an inquiry-based cellulase laboratory. International Journal of Environmental \& Science Education Vol. 5, No. 2, April 2010,169-187.

41. Wiseman, R. 2014. 59 Detik: yang Membuat Anda Lebih Kreatif, Lebih Meyakinkan, dan Lebih Bahagia. Jakarta: Gemilang. 